\title{
Therapeutic hypothermia in stroke and traumatic brain injury
}

\author{
Alireza Faridar ${ }^{1}$, Eric M. Bershad ${ }^{2}$, Tenbit Emiru ${ }^{1}$, Paul A. laizzo ${ }^{3,4}$, Jose I. Suarez ${ }^{2}$ and Afshin A. Divani ${ }^{1,5} *$ \\ 1 Department of Neurology, University of Minnesota, Minneapolis, MN, USA \\ 2 Department of Neurology, Baylor College of Medicine, Houston, TX, USA \\ ${ }^{3}$ Department of Surgery, University of Minnesota, Minneapolis, MN, USA \\ ${ }^{4}$ Department of Integrative Biology and Physiology, University of Minnesota, Minneapolis, MN, USA \\ ${ }^{5}$ Department of Neurosurgery, University of Minnesota, Minneapolis, MN, USA
}

\section{Edited by:}

David S. Liebeskind, University of

California Los Angeles, USA

\section{Reviewed by:}

Richard Zweifler, Sentara Healthcare, USA

Edgard Pereira, JFK Medical Center, USA

\section{${ }^{*}$ Correspondence:}

Afshin A. Divani, Department of Neurology, University of Minnesota, MMC 295, 420 Delaware Street Southeast, Minneapolis, MN 55455 , USA.

e-mail:divani@umn.edu
Therapeutic hypothermia ( $\mathrm{TH})$ is considered to improve survival with favorable neurological outcome in the case of global cerebral ischemia after cardiac arrest and perinatal asphyxia. The efficacy of hypothermia in acute ischemic stroke (AIS) and traumatic brain injury (TBI), however, is not well studied. Induction of TH typically requires a multimodal approach, including the use of both pharmacological agents and physical techniques. To date, clinical outcomes for patients with either AIS or TBI who received TH have yielded conflicting results; thus, no adequate therapeutic consensus has been reached. Nevertheless, it seems that by determining optimal TH parameters and also appropriate applications, cooling therapy still has the potential to become a valuable neuroprotective intervention. Among the various methods for hypothermia induction, intravascular cooling (IVC) may have the most promise in the awake patient in terms of clinical outcomes. Currently, the IVC method has the capability of more rapid target temperature attainment and more precise control of temperature. However, this technique requires expertise in endovascular surgery that can preclude its application in the field and/or in most emergency settings. It is very likely that combining neuroprotective strategies will yield better outcomes than utilizing a single approach.

Keywords: hypothermia, stroke, traumatic brain injury, neuroprotection

\section{INTRODUCTION}

The use of therapeutic hypothermia $(\mathrm{TH})$ as a treatment option for acute neurological injury has evolved over the past century (Krieger et al., 2001). In the 1930s, successful resuscitation following prolonged cold water asphyxia in drowning victims was reported (Gunn and Thoresen, 2006; Linares and Mayer, 2009), which raised the possibility that hypothermia provided a neuroprotective effect in the case of anoxic brain injury (Linares and Mayer, 2009). The first report of TH as a treatment for patients with traumatic brain injury (TBI) was published in 1943 (Fay, 1943), and that was followed by reports from several other investigators touting its potential neuroprotective effects in acute neurological injuries (Metz et al., 1996; Krieger et al., 2001; Schwab et al., 2001; Polderman, 2004; Kollmar et al., 2009). In 1952 at the University of Minnesota, Dr. John Lewis closed an atrial septal defect in a 5-year-old girl using total-body hypothermia. The child's body was cooled to $28^{\circ} \mathrm{C}$ with a cooling blanket and rewarmed in a tank of warm water (Gott, 2005). Currently, clinical application of TH is utilized in during open-heart surgery and after global cerebral ischemia associated with cardiac arrest and prenatal asphyxia (Lazzaro and Prabhakaran, 2008; van der Worp et al., 2010). Although $\mathrm{TH}$ is instituted after other acute neurological injuries such as stroke and TBI, the efficacy of its routine use for these conditions remains unproven (Miyazawa et al., 2003). Additionally, complications including a high risk of infection, cardiac arrhythmias, thrombocytopenia, hypotension, hypokalemia, pancreatitis, gastrointestinal ulcer, liver dysfunction, coagulopathy, and acute heart failure have been reported (De Georgia et al., 2004; Alty and Ford, 2008; Varon and Acosta, 2008; Yenari et al., 2008; Den Hertog et al., 2009). The focus of this review will be to discuss the pathophysiological rationale and evidence-based literature supporting the use of TH in treatment of patients with acute ischemic stroke (AIS) and TBI.

\section{PATHOPHYSIOLOGY OF HYPOTHERMIA}

Hypothermia exerts complex effects on human physiology. In conscious, non-intubated patients it can be difficult to induce $\mathrm{TH}$ without pharmacological interventions because the human body mounts vigorous thermoregulatory defenses. These thermoregulatory mechanisms substantially increase metabolic activity within the body, which may be harmful or at least counter productive as they impede the induction of TH (Busto et al., 1989a; Bandschapp and Iaizzo, 2011).

Thermoregulatory mechanisms can be divided into behavioral and hypothalamic controlled autonomic responses. The behavioral components of these responses (e.g., protection by clothes, shelter, shade, or air conditioning) are ultimately under our conscious control. In clinical settings these behavioral controls are often usurped by healthcare providers (Busto et al., 1989a; Bandschapp and Iaizzo, 2011). The effects or responses governed by the 
autonomic nervous system are the primarily activated responses to cold include arteriovenous shunting or induced vasoconstriction and shivering. In general, cutaneous vasoconstriction is initiated once core temperature decreases to about $36.5^{\circ} \mathrm{C}$, and significant shivering starts at around $35.5^{\circ} \mathrm{C}$. It should be noted that while most blood vessels constrict in response to regional hypothermia, arteriovenous shunting is relatively resistant to local temperature changes and seems to be mainly controlled by central mechanisms (Sessler, 2008). In infants, non-shivering thermogenesis of "brown fat" follows as the next elicited effector response. Interestingly, however, thermogenesis via shivering is totally absent in the newborn and not fully effective until several years of age (Brooke et al., 1973). In contrast, non-shivering thermogenesis is considered to have a relatively minor or marginal physiological role in adults (Jessen, 1980). By definition, shivering is involuntary, oscillatory muscle activity that greatly increases metabolic heat production to counteract hypothermia (Iampietro et al., 1960). Notably, in a hypothermic patient, the elicitation of forceful shivering can increase metabolic heat production several-fold, which exacerbates the patient's condition. Therefore, one needs to consider modulating this response either with muscle paralysis and/or lowering the shivering threshold (Busto et al., 1989a; Bandschapp and Iaizzo, 2011). Muscle paralysis is the most effective way to stop shivering, but increases risk of many adverse events (AEs) including inability to detect changes in the neurological exam, high risk of pneumonia, and prolonged ventilation. Thus, using a pharmacological approach to lower the shivering threshold in awake patients may considerably reduce the need for heavy sedation, paralytics and, therefore, the need for ventilatory support (Guluma et al., 2006). Some pharmacological agents that are used to inhibit shivering include buspirone, meperidine, clonidine, magnesium, and dexmedetomidine (Xue and Huang, 1992; Karibe et al., 1994; Bandschapp and Iaizzo, 2011; Kallmünzer et al., 2011). Several reported pharmacological anti-shivering protocols have allowed investigators to achieve the target temperature (TT) without using heavy sedation or paralytics, often obviating the need for mechanical ventilation (Xue and Huang, 1992; Karibe et al., 1994; Bandschapp and Iaizzo, 2011; Kallmünzer et al., 2011). In some studies, buspirone and meperidine in combination synergistically decreased the shivering threshold to $33^{\circ} \mathrm{C}$, with, notably, minimal sedation or respiratory depression (van Breda et al., 2002; Bandschapp and Iaizzo, 2011). Based on these findings, Lyden et al. (2005) suggested that prophylactic administration of oral buspirone plus intravenous (IV) meperidine could effectively prevent shivering to achieve the TT in awake patients. Another useful technique to reduce shivering is surface counter warming using heating blankets (Guluma et al., 2008). Bandschapp and Iaizzo (2011) combined surface counter warming of the hands and/or face with the use of anti-shivering drugs.

Classically, the primary neuroprotective benefit of $\mathrm{TH}$ has been attributed to a reduction in the cerebral metabolic rate of oxygen $\left(\mathrm{CMRO}_{2}\right)$, which is related to neuronal glucose and oxygen consumption and lactate production. In other words, TH may reduce energy depletion by lowering the $\mathrm{CMRO}_{2}$ and improving glucose utilization (Yenari et al., 2008; Liu and Yenari, 2007). Reportedly, brain oxygen consumption decreases by $5 \%$ per $1{ }^{\circ} \mathrm{C}$ decrease in body temperature. Additionally, slowed metabolism following $\mathrm{TH}$ reduces interstitial lactate accumulation and maintains physiological tissue $\mathrm{PH}$ balance. It has been shown that for every $1^{\circ} \mathrm{C}$ decrease in temperature, the $\mathrm{pH}$ increases by 0.016 (Varon and Acosta, 2008). This lends support to the notion that TH may reduce cerebral injury by reducing acidosis. However, in another study, no decrease was detected in cerebral lactate level following $\mathrm{TH}$ (Busto et al., 1989a). Therefore, one can conclude that TH produces neuroprotective effects through other mechanisms (Busto et al., 1989a).

Beyond reduction of $\mathrm{CMRO}_{2}$, the other neuroprotective mechanisms of TH include: (1) preservation of high-energy organic phosphates; (2) slowed accumulation of lactic acid and other neurotoxins; (3) enhanced glucose utilization; (4) modulation of gene expression; (5) facilitation of anti-inflammatory responses and anti-apoptotic pathways; (6) reduction of intracranial pressure (ICP); (7) stabilization of the blood-brain barrier; (8) inhibition of free radical productions; and (9) reduction of excitotoxic neurotransmitters such as glutamate (Jiang et al., 1992; Miyazawa et al., 2003; Olsen et al., 2003; van der Worp et al., 2007; Varon and Acosta, 2008; Yenari et al., 2008).

In patients presenting with cerebral ischemia, $\mathrm{TH}$ may minimize the extent of injury (Figure 1) by modulating several steps of the ischemic cascade (Lazzaro and Prabhakaran, 2008; Linares and Mayer, 2009). More specifically, in an experimental study using positron emission tomography scan to evaluate the effect

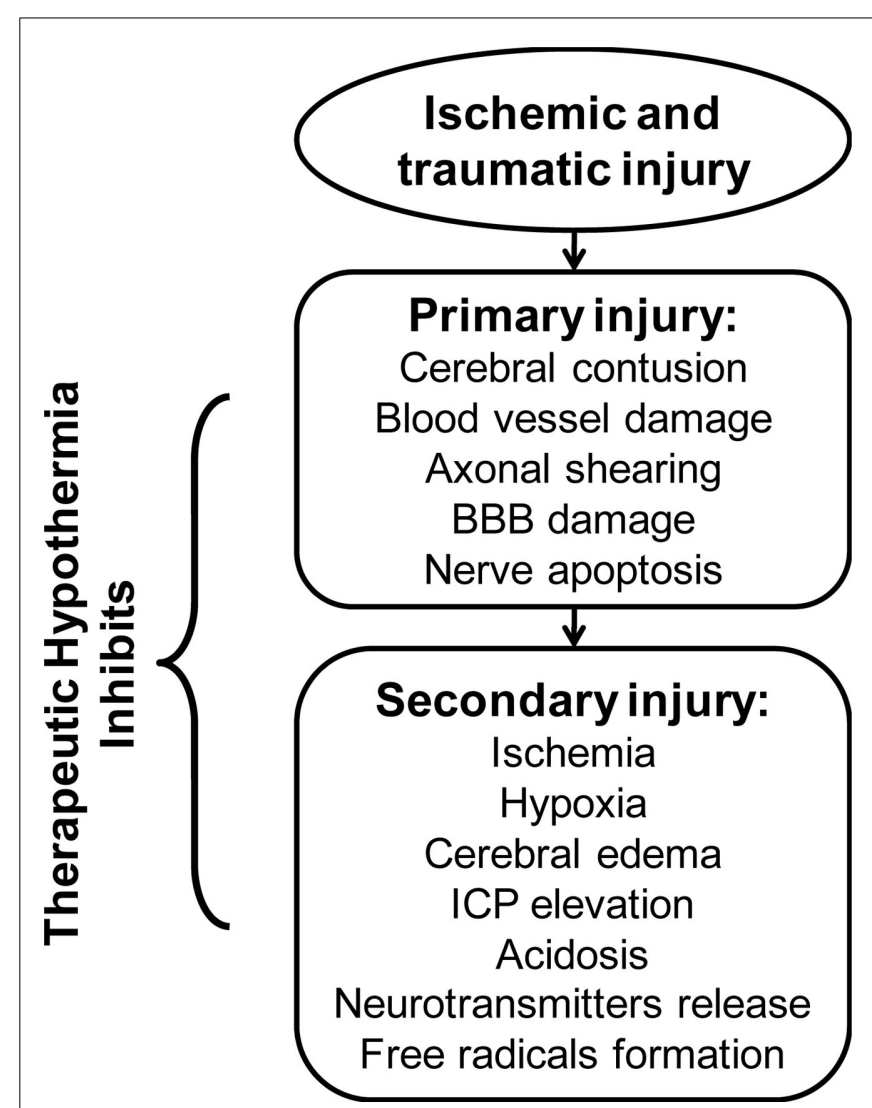

FIGURE 1 | Primary and secondary brain injuries following neurologic events. 
of TH after AIS, reduction in $\mathrm{CMRO}_{2}$ was coupled with decreases in cerebral blood flow $(\mathrm{CBF})$ and minimization of brain tissue necrosis volume (Sakoh and Gjedde, 2003). Furthermore, TH may reduce neuronal excitotoxicity following ischemic depolarization by blocking glutamate and dopamine release (Nakashima and Todd, 1996). For example, in an experimental study, Busto et al. (1989b) demonstrated that mild hypothermia, with a TT between 35 and $36^{\circ} \mathrm{C}$, significantly reduced cerebral dopamine and glutamate release, thus attenuating neurotoxicity. In addition, decreased glutamate accumulation leads to reduced calcium influxes and lipid peroxidation, which then attenuates free radical production (Nakashima and Todd, 1996). Furthermore, TH may inhibit free radical activity following cerebral ischemia by enhancing levels of endogenous antioxidants (Maier et al., 2002). Hashimoto et al. (2004) evaluated the effect of TH on free radical production in a rodent model of cerebral ischemia by cerebellar microdialysis measurements. The experiment revealed temperature-related reduction of free radical production associated with attenuated neuronal damage in both the ischemic and reperfusion phases (Maier et al., 2002; Hashimoto et al., 2004). Finally, TH may favor up-regulation of stress responsive genes, which produce anti-apoptotic proteins such as $\beta$-catenin, which translocate into the nuclei and regulate gene expression, favoring cell survival (Akaji et al., 2003; Lazzaro and Prabhakaran, 2008; Zhang et al., 2008).

It is suggested that $\mathrm{CBF}$ is reduced through arteriolar vasoconstriction during TH, resulting in decreased ICP (Bernard and Buist, 2003; Varon and Acosta, 2008; Yenari et al., 2008). However, in a clinical study of patients with severe TBI, inducing moderate $\mathrm{TH}\left(32-33^{\circ} \mathrm{C}\right)$ resulted in decreased ICP, though CBF was not changed significantly during the therapy; this suggests restoration of blood brain barrier (BBB) function and subsequent reduction in cerebral edema as an underlying mechanism for drop in ICP (Metz et al., 1996). More specifically, pericyte migration from the microvasculature following reperfusion injury normally results in disruption of BBB (Liu and Yenari, 2007; Lazzaro and Prabhakaran, 2008). In the rodent model, however, the induction of $\mathrm{TH}$ in ischemic brain injury inhibited the separation of pericytes from basement membrane, thereby preserving BBB integrity (Duz et al., 2007). Therefore, the intact BBB prevents the leakage of plasma proteins into the brain interstitium post-ischemia possibly reducing cerebral edema formation and the associated rise in ICP. In summary, TH mounts a multi-faceted cascade of neuroprotective mechanisms after cerebral ischemia and TBI (see Figure 1).

\section{THERAPEUTIC HYPOTHERMIA INDUCTION}

The optimal induction method of TH is currently unknown. Desirable characteristics of the TH method include safety, rapid cooling speed, easy implementation, widespread availability, and low financial costs. It is almost certain that a multimodal approach will be required, likely combining pharmacological agents and physical techniques, and keeping in mind the transition from the prehospital to hospital setting (Den Hertog et al., 2009).

\section{PHARMACOLOGICAL COOLING}

Pharmacological agents include antipyretics and non-steroidal anti-inflammatory agents. Unfortunately, the use of non-steroidal anti-inflammatory drugs (i.e., ibuprofen) or antipyretic drugs (i.e., acetaminophen) for $\mathrm{TH}$ has shown only a modest reduction in temperature (Dippel et al., 2001, 2003; Koennecke and Leistner, 2001; Kasner et al., 2002; Aiyagari and Diringer, 2007; Linares and Mayer, 2009), and therefore is insufficient alone to produce clinically significant hypothermia.

\section{MECHANICAL COOLING}

There are many options available for systemic or regional body cooling. Systemic methods include either surface cooling or intravascular cooling (IVC). Surface cooling techniques such as water-circulating cooling blankets, ice-packs, water mattresses, icewater and alcohol baths, whole body ice rubs, electric cooling fans, and/or forced air cooling have been studied in numerous small clinical trials (Schwab et al., 1998, 2001; Kammersgaard et al., 2000; Krieger et al., 2001; Abou-Chebl et al., 2004; Mayer et al., 2004; Jordan and Carhuapoma, 2007; Den Hertog et al., 2009). Endovascular cooling includes intravenous icesaline infusion into peripheral or central veins, and active cooling catheters intra-arterially or intravenously (Lenhardt et al., 2009).

\section{SURFACE COOLING}

Surface cooling is easy to implement, but usually induces severe shivering which may require heavy sedation and/or paralysis with neuromuscular blockade (Lazzaro and Prabhakaran, 2008). In addition, it is often challenging to maintain body temperature at a desired level via surface cooling. In one study, surface cooling induced hypothermia led to overcooling in 9 of 10 subjects (Zweifler et al., 2003; Guluma et al., 2006). However, active surface cooling using the Arctic Sun Temperature Management System (Medivance, Louisville, CO, USA) was more effective than conventional surface cooling methods, such as the cooling-blanket, for controlling fever in critically ill neurologic patients (Mayer et al., 2004). This device has a feedback mechanism to actively regulate the body temperature to a specific target. The main limitation of this device is that it is somewhat labor intensive, and the disposable cooling pads are expensive.

Based on the limitation of general surface cooling, interest has focused on regional cooling, such as by using selective head and/or neck cooling (Wang et al., 2004; Qiu et al., 2006). In one study, head cooling lowered temperature to $34^{\circ} \mathrm{C}$, but took several hours to reach, likely related to low skull thermal conductivity (Harms et al., 2008). Additionally, while selective head cooling may reduce the superficial cortical temperature, it may not cool deeper brain structures to the same level (Chen et al., 2009). However, concurrent neck cooling was found to increase cooling efficiency of lowering core body temperature (Keller et al., 2009). A novel method of prehospital trans-nasal evaporative cooling has been applied in patients with witnessed cardiac arrest recently. In this method, a liquid coolant-oxygen mixture is sprayed into the nasal cavity, which rapidly evaporated with high-flow oxygen, results in significant cooling of the nasal passages and brain. This trial presented the feasibility of this method with improvement in the time intervals required to cool patients. However, some device-related AEs including nasal whitening, epistaxis, and peri-orbital emphysema have been occurred (Castren et al., 2010). 


\section{INTRAVASCULAR COOLING}

Intravascular cooling has some advantages to surface cooling, but also carries certain risks as it is usually an invasive technique. In general, as no surface equipment such as cooling blanket or pads are needed, one can institute surface counter warming, resulting in the attenuation of the shivering response while concurrently allowing for efficient cooling of the core blood volume (Polderman et al., 2005; Lazzaro and Prabhakaran, 2008). The average time to achieve the TT has been shown to be considerably shorter ( $\sim 70 \mathrm{~min}$ ) using IVC compared to surface cooling (3-8 h; Keller et al., 2003). A possible explanation for this is that surface cooling triggers cutaneous vasoconstriction which reduces conduction surface area (Guluma et al., 2006). In contrast, a local intra-arterial infusion of cold saline may achieve TT within a few minutes. The rapid attainment of the TT may enhance neuroprotection and also expand the therapeutic time-window for other treatment strategies, but further data is needed to confirm this (Konstas et al., 2007). However, the required experience with endovascular techniques prevents an easy widespread application (van der Worp et al., 2010). Some possible specific adverse effects of IVC include a higher risk for infection, deep venous thrombosis (DVT), and vascular dissection (Schwab et al., 2001). Simosa et al. (2007) evaluated the risks of DVT with duplex sonogram in TBI patients who underwent intravascular TH. They observed a DVT rate of $33 \%$ if the catheter were removed within 4 days but the rate was increased up to $75 \%$ when the catheter was removed after 4 days. Therefore, it may be prudent to monitor patients closely with duplex ultrasonography for DVT if an IVC method is used. Some novel techniques of invasive cooling induction are currently under investigation. A few experimental studies have evaluated the technical feasibility of epidural surface cooling induction. The outcomes were promising in attaining the rapid TT with unchanged physiologic and hemodynamic variables (Zweifler et al., 2003; Qiu et al., 2006).

\section{CORE BODY TEMPERATURE ASSESSMENT}

The best method for assessing core body temperature is uncertain. Currently, core body temperature is estimated using a variety of probes, including rectal, tympanic, bladder, esophageal, or vaginal probes (Nolan et al., 2003). Unfortunately, the temperatures recorded in these different sites may vary by up to several degrees, and it is not clear how they correlate with brain or core body temperature. For example, in one study it was observed that rectal or bladder temperatures were $1-2^{\circ} \mathrm{C}$ lower than monitored brain temperatures, and at temperatures above 38 or below $36^{\circ} \mathrm{C}$, the differences became even greater (Henker et al., 1998). Thus, further investigations are needed to determine clinically applicable, non-invasive, accurate ways to approximate brain temperature.

\section{THERAPEUTIC HYPOTHERMIA IN STROKE}

The use of TH has been well established to improve survival with favorable neurological outcome in the case of global cerebral ischemia after cardiac arrest or perinatal hypoxia-ischemic insult; however, the efficacy of $\mathrm{TH}$ for treating focal cerebral ischemia has not yet been well studied (Abate et al., 2008). However, in reported animal studies, TH has consistently reduced infarct sizes when applied before or early after the onset of cerebral ischemia (Xue and Huang, 1992; Karibe et al., 1994).

In the last decade, various clinical trials have attempted to evaluate the potential benefits of utilizing pharmacological and/or physical TH in AIS (Tables 1 and 2). More specifically, in such pharmacological trials, the efficacies of low- and high-dose administration of paracetamol, metamizole, or ibuprofen have been assessed (Dippel et al., 2001, 2003; Koennecke and Leistner, 2001; Kasner et al., 2002; van Breda et al., 2002; Kallmünzer et al., 2011). A pooled analysis showed only a modest reduction of $0.2^{\circ} \mathrm{C}$ temperature $24 \mathrm{~h}$ after administration. Therefore, as expected, clinical trials did not show any significant clinical benefit with these agents (Den Hertog et al., 2009).

Given the lack of efficacy of the aforementioned pharmacological cooling protocols, we now turn our attention to physical cooling trials. In one such report, Schwab et al. (1998) applied surface cooling for TH in 25 patients with malignant middle cerebral artery infarction and observed beneficial reduction of ICP. Furthermore, the treated patients showed more favorable outcomes and reduced mortality rates than historical controls with similar stroke severity. Notably, nearly half of the deaths in TH-treated patients occurred during the rewarming phase, possibly in relation to a rebound in ICP. It was suggested that a longer rewarming period may be needed to diminish the rebound ICP elevation (Schwab et al., 2001).

Other clinical trials have evaluated the optimal duration of TH once the TT is achieved. In the Copenhagen stroke study, investigators assessed the efficacy of $6 \mathrm{~h}$ of surface cooling in 17 AIS patients (Kammersgaard et al., 2000). Unfortunately, no benefit in terms of outcome was observed. It has been suggested, however, that a longer hypothermia duration of $48-72 \mathrm{~h}$ may be required to reduce the formation of cerebral edema which occurs the most during the first 72-h after symptom onset (Georgiadis et al., 2001). Concerns, however, include the correlation between increased duration of $\mathrm{TH}$ and increased number of AEs; therefore, limiting $\mathrm{TH}$ to $24 \mathrm{~h}$ may be better (Kammersgaard et al., 2000).

Table 1 | Published studies on the role of pharmacological TH in stroke patients.

\begin{tabular}{|c|c|c|c|c|}
\hline Investigator & Year & No of cases & Intervention & Mean ${ }^{\circ} \mathrm{C}$ reduction \\
\hline Kallmünzer et al. & 2011 & 77 & Paracetamol, Metamizole, calf packing & NA \\
\hline Dippel et al. & 2003 & 75 & 6000 mg Paracetamol/day, 2400 mg Ibuprofen/day & $0.3^{\circ} \mathrm{C}$ \\
\hline Kasner et al. & 2002 & 39 & 3900 mg Paracetamol/day & $0.22^{\circ} \mathrm{C}$ \\
\hline Dippel et al. & 2001 & 75 & 6000 mg Paracetamol/day, 3000 mg Paracetamol/day & $0.4^{\circ} \mathrm{C}$ \\
\hline Koennecke and Leistner & 2001 & 42 & 4000 mg Acetaminophen/day & NA \\
\hline
\end{tabular}


Table 2 | Published studies on the role of surface and intravascular TH in stroke patients.

\begin{tabular}{|c|c|c|c|c|c|c|c|c|}
\hline Study & Year & $\begin{array}{l}\text { No of } \\
\text { cases }\end{array}$ & Intervention & Target ( $\left.{ }^{\circ} \mathrm{C}\right)$ & $\begin{array}{l}\text { Time to } \\
\text { target }\left({ }^{\circ} \mathrm{C}\right)\end{array}$ & $\begin{array}{l}\text { Rewarming } \\
\text { time }\end{array}$ & Side effect & Outcomes \\
\hline Hemmen et al. & 2010 & 28 & $\begin{array}{l}\text { Intravascular hypother- } \\
\text { mia + fibrinolysis }\end{array}$ & 33 & $67 \mathrm{~min}$ & $0.3^{\circ} \mathrm{C} / \mathrm{h}$ & $\begin{array}{l}\text { Pneumonia in } \\
\text { cases }\end{array}$ & No difference \\
\hline Kollmar et al. & 2009 & 10 & $\begin{array}{l}\text { Iced cold saline } \\
\text { infusion }\end{array}$ & 35.4 & $52 \min$ & NA & Well tolerated & NIHSS improved (4 scores) \\
\hline Guluma et al. & 2008 & 18 & Intravascular cooling & 33 & - & $12 \mathrm{~h}$ & $\begin{array}{l}\text { Higher NIHSS } \\
\text { in the case } \\
\text { group }\end{array}$ & Reduction of edema \\
\hline Guluma et al. & 2006 & 10 & Intravascular cooling & 33.4 & $1.7 \mathrm{~h}$ & $0.3^{\circ} \mathrm{C} / \mathrm{h}$ & NA & No shivering \\
\hline Lyden et al. & 2005 & 16 & $\begin{array}{l}\text { Intravascular } \\
\text { cooling + fibrinolysis }\end{array}$ & 33 & $7 \mathrm{~h}$ & $12 \mathrm{~h}$ & DVT & NA \\
\hline De Georgia et al. & 2004 & 18 & Intravascular cooling & 35 & $77 \mathrm{~min}$ & NA & NA & $\begin{array}{l}\text { Decreased mean diffusion- } \\
\text { weighted imaging lesion } \\
\text { growth in cases }\end{array}$ \\
\hline Schwab et al. & 2001 & 50 & Surface cooling & 33 & $6.5 h$ & $17 \mathrm{~h}$ & $\begin{array}{l}\text { Pneumonia, } \\
\text { secondary rise } \\
\text { of ICP }\end{array}$ & $\begin{array}{l}\text { Relatively decreased mor- } \\
\text { tality }\end{array}$ \\
\hline Georgiadis et al. & 2001 & 6 & Intravascular cooling & $32.2-33.4$ & $3 h$ & NA & $\begin{array}{l}\text { Bradycardia } \\
\text { infection }\end{array}$ & NA \\
\hline Krieger et al. & 2001 & 10 & $\begin{array}{l}\text { Cooling } \\
\text { blanket }+ \text { fibrinolysis }\end{array}$ & 32 & $3.5 \mathrm{~h}$ & $0.21^{\circ} \mathrm{C} / \mathrm{h}$ & $\begin{array}{l}\text { Sinus } \\
\text { bradycardia }\end{array}$ & NA \\
\hline Kammersgaard et al. & 2000 & 17 & Surface cooling & 35.5 & $6 \mathrm{~h}$ & NA & Pneumonia & $\begin{array}{l}\text { Insignificant lower mortal- } \\
\text { ity rate and improved clini- } \\
\text { cal outcomes in cases }\end{array}$ \\
\hline Schwab et al. & 1998 & 25 & Surface cooling & 33 & $3.5-6.2 \mathrm{~h}$ & $18 \mathrm{~h}$ & Pneumonia & Reduction of ICP \\
\hline
\end{tabular}

Georgiadis et al. (2001) evaluated the feasibility of IVC in six patients with AIS. The clinical outcomes were considered equal to those obtained by surface cooling, demonstrating IVC as a viable option for TH (De Georgia et al., 2004; Lyden et al., 2005; Guluma et al., 2006). Moreover, it should be mentioned again that IVC allows for concurrent use of surface warming to reduce shivering (Guluma et al., 2006). For example, in a pilot study by Kollmar et al. (2009), rapid infusion of ice-cold saline combined with antishivering pharmacological therapy in 10 AIS patients significantly improved discharge NIH stroke scale scores without increasing major side effects. Similarly, Lyden et al. (2005) evaluated several anti-shivering methods in 10 awake patients who underwent IVC after AIS. They reported that a combination of oral buspirone with IV meperidine (load and maintenance) in addition to surface warming blankets allowed for the efficient induction of $\mathrm{TH}$ while minimizing shivering.

Recently, the COOL AID study evaluated the feasibility of IVC in 18 AIS patients compared to 22 control AIS patients (De Georgia et al., 2004). It was reported that there was less diffusion-weighted imaging volume growth in the hypothermic patients compared to the control group, but the long-term clinical outcomes were not significantly different. Nevertheless, this pilot study was not powered for efficacy, and therefore a larger-scale trial may be warranted. In another clinical study, Guluma et al. (2008) evaluated the role of TH using IVC in 18 AIS patients. They found that patients who were effectively cooled to a temperature of less than $34.5^{\circ} \mathrm{C}$ within $8 \mathrm{~h}$ of cooling initiation had a decreased amount of cerebral edema compared to control patients or those who did not achieve the TT. In contrast, Hemmen et al. (2010) studied the feasibility and safety of TH combined with IV t-PA after AIS among patients who were randomized to t-PA and TH $(n=28)$, or t-PA $(n=30)$ alone. They reported that there were no significant differences in symptomatic ICH rates, modified Rankin Scale scores, or mortality at 3 months; however, more patients in the TH group developed pneumonia $(p=0.001)$. The relative lack of efficacy in the TH group may be related to relatively long induction times (median $7 \mathrm{~h}$ ) required to achieve the TT and the small sample size in the study.

It looks as though TH could be an appropriate adjuvant therapy to t-PA for AIS. It also has a potential for utilization in combinational therapeutic strategies with other neuroprotective medication such as caffeinol or hemicraniotomy in malignant supratentorial infraction (Els et al., 2006; Martin-Schild et al., 2009). However, based on the relatively small clinical trials available in the literature, it is apparent that much work is needed to clarify many issues for AIS patients. These include the optimal depths and durations of cooling, improved techniques to reach TT in an optimized time-window, clinically safe rewarming rates, and/or the best anti-shivering measures as discussed previously (MacLellan et al., 2009). Only once the practical aspects of TH in AIS patients are worked out can the efficacy of $\mathrm{TH}$ possibly be determined in a large, multicenter clinical trial. 


\section{THERAPEUTIC HYPOTHERMIA IN TBI}

From a historical perspective, TH for TBI patients was first introduced by Fay (1943) and Marion et al. (1997). Since then, several case series have reported heterogeneous outcomes for patients with TBI receiving TH (Rosomoff and Holaday, 1954; Lazorthes and Campan, 1958; Hendrick, 1959; Sedzimir, 1959; Drake and Jory, 1962; McIntyre et al., 2003). Nevertheless, despite numerous successes of $\mathrm{TH}$ in animal models, the efficacy of routine $\mathrm{TH}$ for TBI patients in the clinical setting is not definitely established (Buchan and Pulsinelli, 1990; Minamisawa et al., 1990; Clifton et al., 1991; Dietrich et al., 1994). In 1993, three different TBI trials demonstrated the feasibility and efficacy of TH to improve clinical outcomes in small trials (Clifton et al., 1993; Marion et al., 1993; Shiozaki et al., 1993). In 1997, a clinical trial evaluated the impact of surface cooling on 40 TBI patients (Marion et al., 1997). Although there was no efficacy for the cohort of patients with the most severe TBI [i.e., Glasgow Coma Scale (GCS) of 3-4 on admission], TH was found to benefit patients with initial GCS of 5-7 in terms of their long-term clinical outcome and mortality. This clinical trial showed that the interleukin-1b and glutamate levels in CSF were significantly reduced in the hypothermic group even after rewarming. Interestingly, the glutamate levels in the patients who did not benefit from hypothermia (GCS of 3 or 4) were similar to those with corresponding GCS scores in the normothermic group. Subsequently, in a larger study performed by Clifton et al., 2001; $n=392$ ), fewer patients in the hypothermia group had elevated ICP. They did, however, have more complications and longer hospital stays, especially in patients older than 45-years. Similarly, Marion et al. (1997) found no improvement in neurological outcomes or survival in TH patients with initial GCS of 5-8. It should perhaps be considered that initial differences in the baseline characteristics of the patients in these separate studies might be a primary underlying factor influencing the differing results. For example, in the study by Marion et al. (1997) a high proportion of patients in normothermic group were described as being in a hypothermic state at the time of admission and were thus actively warmed after admission, which itself may have led to a poorer outcome (Clifton et al., 2001).

In an effort to clarify the heterogeneous and conflicting results regarding the efficacy of $\mathrm{TH}$ for patients with $\mathrm{TBI}$, a systematic review was performed in 2003 which pooled data from 12 published clinical trials. Overall, this analyses included 1069 patients who were split into a hypothermia group $(n=543)$ and a control group ( $n=526$; McIntyre et al., 2003). From this retrospective analysis, it was suggested that inducing $\mathrm{TH}$ for $24 \mathrm{~h}$ significantly reduces the risk of poor neurological outcome. Furthermore, patients who received $\mathrm{TH}$ for more than $48 \mathrm{~h}$ had increased survival. In addition, this analysis suggested that greatest clinical benefits were derived when patients were cooled to a TT of 32$33^{\circ} \mathrm{C}$. Subsequent to this report, Tokutomi et al. (2009) evaluated the clinical outcomes and systemic complications of $\mathrm{TH}$ in two different groups of patients with TBI who were cooled to either 35 or $33^{\circ} \mathrm{C}$. Despite the findings from the previous systematic review (McIntyre et al., 2003), Tokutomi and co-workers' study paradoxically showed lower systemic complication and mortality rate in the milder hypothermia $\left(35^{\circ} \mathrm{C}\right)$ group. These outcomes were similar to those observed by Shiozaki et al. (2003) who did not find any benefit in cooling TBI patients from 34 to $31^{\circ} \mathrm{C}$ with refractory ICP, defined as being higher than $40 \mathrm{mmHg}$ despite first line treatments.

It should be considered that severe TBI patients may have physical restrictions imposed on their clinical management by systemic trauma, potentially making surface cooling difficult to implement in such individuals (Sahuquillo et al., 2009). With this scenario in mind, Harms et al. (2008) applied a cooling helmet in TBI patients. This approach was considered to have failed, however, as it was not effective in reaching the target brain temperature in most patients. Table 3 summarizes other approaches of using $\mathrm{TH}$ in TBI patients. In the IntraCool study in which therapy was applied to IVC patients with severe TBI and refractory elevated ICP $(n=28)$, a significant reduction in ICP and mortality rate was observed (Sahuquillo et al., 2009). Likewise, a study by Puccio et al. (2009) showed that even an induced normothermia protocol utilizing IVC ameliorated secondary brain injuries, perhaps by reducing the ICP. In 2010, a comprehensive review evaluating 23 clinical trials including results from 1614 randomized patients reported that the $\mathrm{TH}$ group had better neurological outcomes and reduced mortality rate (Sydenham et al., 2009). Significant benefit was only found in trials with open label or uncertain masking designs, however, which, notably, may have led to examiner bias. Importantly, in the nine of these trials with adequate masking procedures, no significant benefit in clinical outcomes was observed. Similarly, a meta-analysis of six clinical trials of TBI patients revealed that treated individuals with hypothermia had a $46 \%$ increased likelihood of favorable neurological outcome, defined as a Glasgow Outcome Score of 4-5 (Bratton et al., 2007). Despite this increased likelihood of favorable neurological outcome, no significant reductions in all-cause mortality were observed in TH patients. As such, the aforementioned results are in contrast to the 2003 systematic review (McIntyre et al., 2003) that suggested reduced mortality when cooling was maintained for more than $48 \mathrm{~h}$. In response to such reported inconsistencies in the effects of TH on TBI patients, Clifton et al. (2011) recently designed a multicenter, double-blind study to specifically assess the potential neuroprotective effects of early induction of $\mathrm{TH}$ on the outcomes of TBI. In this study, the mean time to reach core temperature of $35^{\circ} \mathrm{C}$ in the patients in the hypothermic group was $2.6 \mathrm{~h}$ after injury. Nevertheless, their results did not show any significant superiority in clinical outcomes in the TH group $(n=119)$ when compared to normothermic patients $(n=113)$. Also, inexplicably, a significantly higher proportion of patients in the $\mathrm{TH}$ group had episodes of increased ICP. Therefore, there remains a need for further clarification through well-designed clinical trials in such TBI patients to determine which or whether any patient subgroups may benefit from $\mathrm{TH}$.

\section{DISCUSSION}

Currently, protocols to administer $\mathrm{TH}$ are well established for patients who suffer out-of-hospital cardiac arrest or for neonates with hypoxic-ischemic encephalopathy (Abate et al., 2008). Clinical outcomes for patient populations with either AIS or TBI that had received $\mathrm{TH}$ therapy have yielded conflicting results and therefore no adequate clinical consensus for use in these types of patients has been reached (Abate et al., 2008; Arcure and Harrison, 
Table 3 | Published studies evaluating the role of therapeutic hypothermia in TBI patients.

\begin{tabular}{|c|c|c|c|c|c|c|c|c|c|}
\hline Study & Year & $\begin{array}{l}\text { No of } \\
\text { cases }\end{array}$ & $\begin{array}{l}\text { Cooling } \\
\text { method }\end{array}$ & Target ( $\left.{ }^{\circ} \mathrm{C}\right)$ & $\begin{array}{l}\text { Time to } \\
\text { Target } \\
\left.\text { ( }{ }^{\circ} \mathrm{C}\right)\end{array}$ & $\begin{array}{l}\text { Duration } \\
\text { of hypo- } \\
\text { thermia }\end{array}$ & Rewarming & Outcomes & Side effect \\
\hline $\begin{array}{l}\text { Clifton } \\
\text { et al. }\end{array}$ & 2011 & 52 & $\begin{array}{l}\text { Surface } \\
\text { cooling }\end{array}$ & 33 & 4.4 & $48 h$ & $0.5^{\circ} \mathrm{C} / 2 \mathrm{~h}$ & $\begin{array}{l}\text { Improved clinical outcomes in } \\
\text { patients with evacuated } \\
\text { hematoma }\end{array}$ & $\mathrm{ICP}$ rise \\
\hline $\begin{array}{l}\text { Harms } \\
\text { et al. }\end{array}$ & 2008 & 12 & $\begin{array}{l}\text { Cooling } \\
\text { cap }\end{array}$ & 33 & NA & $24 \mathrm{~h}$ & $24 h$ & $\begin{array}{l}\text { Cooling cap was not capable to } \\
\text { reach the target temperature }\end{array}$ & $\begin{array}{l}\text { Higher mortality } \\
\text { rate in cases }\end{array}$ \\
\hline $\begin{array}{l}\text { Tokutomi } \\
\text { et al. }\end{array}$ & 2009 & 30 vs. 31 & $\begin{array}{l}\text { Surface } \\
\text { cooling }\end{array}$ & 35 vs. 33 & NA & NA & NA & $\begin{array}{l}\text { The mortality rate and the } \\
\text { incidence of systemic } \\
\text { complications tended to be } \\
\text { lower in the } 35 \text { degree group } \\
\text { than } 31 \text { degree }\end{array}$ & - \\
\hline $\begin{array}{l}\text { Sahuquillo } \\
\text { et al. }\end{array}$ & 2009 & 24 & $\begin{array}{l}\text { Intravascular } \\
\text { cooling }\end{array}$ & 32.5 & $3 \mathrm{~h}$ & $155.3 \mathrm{~h}$ & $1^{\circ} \mathrm{C} /$ day & $\mathrm{ICP}$ reduction in refractory cases & $\begin{array}{l}\text { Rebound ICP rise } \\
\text { arrhythmia }\end{array}$ \\
\hline $\begin{array}{l}\text { Puccio } \\
\text { et al. }\end{array}$ & 2009 & 21 & $\begin{array}{l}\text { Intravascular } \\
\text { cooling }\end{array}$ & 36.5 & NA & $72 \mathrm{~h}$ & NA & Reduce fever burden & - \\
\hline $\begin{array}{l}\text { Adelson } \\
\text { et al. }\end{array}$ & 2005 & 23 & $\begin{array}{l}\text { Surface } \\
\text { cooling }\end{array}$ & $32-33$ & $4.99 h$ & $48 \mathrm{~h}$ & $1^{\circ} \mathrm{C} / 3-4 \mathrm{~h}$ & TH decrease mortality & $\begin{array}{l}\text { Arrhythmia } \\
\text { rebound ICP rise }\end{array}$ \\
\hline $\begin{array}{l}\text { Shiozaki } \\
\text { et al. }\end{array}$ & 2003 & 22 & $\begin{array}{l}\text { Surface } \\
\text { cooling }\end{array}$ & 31 vs. 34 & $3 h$ & NA & NA & $\begin{array}{l}\text { Moderate hypothermia is not } \\
\text { effective in improving clinical } \\
\text { outcomes in TBI with refractory } \\
\text { ICP after mild hypothermia }\end{array}$ & $\begin{array}{l}\text { More sever compli- } \\
\text { cation in } 31^{\circ} \mathrm{C}\end{array}$ \\
\hline Zhi et al. & 2003 & 198 & $\begin{array}{l}\text { Surface } \\
\text { cooling }\end{array}$ & $32-35$ & NA & $62.4 \mathrm{~h}$ & NA & $\begin{array}{l}\text { TH reduce mortality and improve } \\
\text { prognosis }\end{array}$ & $\begin{array}{l}\text { Less sever compli- } \\
\text { cation in } \mathrm{TH} \text { group }\end{array}$ \\
\hline $\begin{array}{l}\text { Clifton } \\
\text { et al. }\end{array}$ & 2001 & 199 & $\begin{array}{l}\text { Surface } \\
\text { cooling }\end{array}$ & 33 & $8 h$ & $48 h$ & $0.5^{\circ} \mathrm{C} / \mathrm{h}$ & Decreased ICP crisis & $\begin{array}{l}\text { More hospital stay } \\
\text { critical hypotension }\end{array}$ \\
\hline $\begin{array}{l}\text { Shiozaki } \\
\text { et al. }\end{array}$ & 2001 & 45 & $\begin{array}{l}\text { Surface } \\
\text { cooling }\end{array}$ & 34 & NA & $48 \mathrm{~h}$ & $1^{\circ} \mathrm{C} /$ day & $\begin{array}{l}\text { No advantage in } \mathrm{TH} \text { over } \\
\text { normothermia }\end{array}$ & $\begin{array}{l}\text { Pneumonia menin- } \\
\text { gitis }\end{array}$ \\
\hline
\end{tabular}

2009). It is noteworthy that recently several systematic reviews, which pooled data from heterogeneous clinical trials with different cooling methods, failed to show any significant improvement in clinical outcomes after induction of hypothermia (Den Hertog et al., 2009; Sydenham et al., 2009). It is important to note, however, that in more recent trials using IVC in awake patients, the reported outcomes are more promising (Guluma et al., 2008; Puccio et al., 2009; Sahuquillo et al., 2009). More specifically, the application of IVC elicited both the capability of more rapid TT attainment and more precise control of temperature (Guluma et al., 2006).

Early intra-ischemia cooling induction is supposed to modify ischemia-induced as well as post-reperfusion cellular abnormalities, but delayed $\mathrm{TH}$ induction is thought to target only the post-reperfusion cell death and inflammatory signaling pathways (Lampe and Becker, 2011). In experimental studies, the best chance of neurological recovery has been achieved by inducing hypothermia within $15 \mathrm{~min}$ following initiation of ischemia (Kim et al., 2009). This shows that reaching the optimal core body temperature early in the therapeutic window can have a principal impact on the outcome. Typically, the systems to provide IVC are not portable and the therapy can only be initiated after the patient arrives at the hospital. Thus, the imposed delay in treatment may reduce the possibilities for achieving optimal outcome. To overcome this problem, in a pilot study, Kim et al. evaluated the feasibility of IV infusion of up to $2 \mathrm{~L}$ of $4^{\circ} \mathrm{C}$ normal saline by paramedics in the field after cardiac arrest. The clinical outcomes were promising, showing an effective lowering of the core temperature in patients without any remarkable side effects (Kim et al., 2007). Kollmar et al. (2009) also assessed the impact of infusing $25 \mathrm{~mL} / \mathrm{kg}$ of icecold saline within the first $3 \mathrm{~h}$ after AIS. They demonstrated that ice-cold saline might be useful to deliver hypothermia within a neuroprotective treatment window in stroke. Therefore, one could potentially apply a portable ice-cold saline method before arriving at the hospital, where subsequent classical IVC intervention would take place (Harms et al., 2008; Clifton et al., 2011).

Earlier studies expressed that the induction of moderate $\mathrm{TH}$ induces the optimal benefit in reducing neurological injury (Maier, 1998; McIntyre et al., 2003). In an experimental study, Kollmar et al. (2007) demonstrated that the greatest histological and functional benefits were achieved with a TT of $35^{\circ} \mathrm{C}$. Consistent with this finding, several recent clinical trials also did not report any clinical benefits in cooling their patients to TTs lower than $35^{\circ} \mathrm{C}$ (Shiozaki et al., 2003; Tokutomi et al., 2009). Furthermore, it seems that the induction of mild TH may produce good clinical outcomes while also minimizing the occurrences of some AEs (Schubert et al., 2008; MacLellan et al., 2009).

In addition to shivering, $\mathrm{TH}$ can encounter the patient to a wide range of many other adverse effects including infection, hemodynamic instability, and electrolyte imbalance (Lampe and Becker, 2011). The most common infectious complication is 
pneumonia, which happens frequently in proportion to duration and degree of hypothermia (Lampe and Becker, 2011). In patients with space-occupying hemispheric infarction treated with induced hypothermia, pneumonia rates reach up to $83 \%$ following cooling induction (van der Worp et al., 2010). To overcome this complication, Harms et al. (2008) have suggested prophylactic antibiotic therapy that can have a considerable impact on the subsequent morbidities and mortalities in TH patients. Hemodynamic AEs following cooling induction includes hypotension, bradycardia, and arrhythmia (Froehler and Ovbiagele, 2010). Among them, bradycardia has been observed in up to $50 \%$ of subjects following cooling induction (De Georgia et al., 2004; Froehler and Ovbiagele, 2010). However, it tends to be well tolerated and has not been reported to cause any clinical sequel (Froehler and Ovbiagele, 2010). Furthermore, cooling induction can shift the electrolytes out of the intravascular space, leading to deep hypokalemia, hypomagnesemia, and hypophosphatemia. Opposite electrolyte derangements can also occur during the rewarming phase (Nohl and Jordan, 1986; Turrens et al., 1991; Lampe and Becker, 2011). Therefore, for detecting these cooling-induced AEs in the earlier stages, the patient's vital signs, cardiac rhythm, and serum electrolytes levels should be monitored during hypothermic states (Froehler and Ovbiagele, 2010). In the subsequent rewarming phase, most patients have a tendency to become hyperthermic with rebound rises in ICP (Lampe and Becker, 2011). It has been suggested that controlled slow rewarming within $24 \mathrm{~h}$ can minimize or prevent rebound rises in ICP and thus associated, subsequent adverse neurological effects (Schwab et al., 2001; McIntyre et al., 2003). It should be mentioned, however, that in the latest guidelines for the management of TBI, a subgroup of analyses did not suggest any clear relationship between cooling durations or rates of rewarming and improved clinical outcomes (Bratton et al., 2007).

We also consider here that careful evidence-based selection of $\mathrm{TH}$ candidates will help the ultimate neuroprotective effects to become more apparent in future trials. More specifically, it appears that patients older than 45 years and those with various co-morbidities have more reported complications and longer hospital stays after induced hypothermia; thus, they may not benefit from this treatment option as much as a younger patient should (Clifton et al., 2001; De Georgia et al., 2004). It has also been shown that TH leads to significantly better clinical outcomes with reduced mortality rates in patients with a GCS of 5 or higher on admission (Marion et al., 1997). In general, promising indicators for successful $\mathrm{TH}$ include younger patients and those that have undergone a thorough neurological exam on admission. Furthermore, those patients with TBI who undergo surgical removal of intracranial hematomas should have a better outcome relative to diffuse brain injury cases after hypothermia induction (Clifton et al., 2011). Finally, another group of patients who can benefit from $\mathrm{TH}$ are patients with refractory high ICP values. To date, many trials have presented satisfactory effects of $\mathrm{TH}$ in reducing ICP in patients who may have suffered a stroke or TBI (Schwab et al., 2001; Sahuquillo et al., 2009). Evidently, clinical trials are currently conducted to better clarify the evidence-based indications (Table 4) to better clarify the evidence-based indications.

The application of $\mathrm{TH}$ for other acute neurological injuries such as subarachnoid hemorrhage, spinal cord injury (SCI), and drug resistant epilepsy has been reported (Levi et al., 2009, 2010; Anei et al., 2010; Motamedi et al., 2011), but awaits further study before the routine use can be recommended. In preclinical settings, institution of $\mathrm{TH}$ has led to reduced gray and white matter damage and improved motor function in rodent models of SCI (Basso et al., 1996; Yu et al., 2000; Dietrich, 2009). In 2010, attention was brought to a case report of a professional NFL football player who sustained a complete cervical SCI during game-related trauma. The patient received experimental TH along with other routine medical and surgical interventions. The marked neurological improvement in this case made $\mathrm{TH}$ a hotly debated topic for management of SCI patients (Cappuccino et al., 2010). A phase I clinical trial evaluated the possibility of applying systemic $\mathrm{TH}$ in 14 patients with complete cervical SCI. The clinical outcomes were

Table 4 | Ongoing clinical trials for evaluating the possible role of therapeutic hypothermia in stroke and TBI*.

\begin{tabular}{|c|c|c|c|}
\hline Study title & Design & Intervention & Target enrollment \\
\hline $\begin{array}{l}\text { Intravenous thrombolysis plus hypothermia for acute treatment of } \\
\text { ischemic stroke }\end{array}$ & Phase I, randomized, case-control & $\mathrm{TH}+\mathrm{t}-\mathrm{PA}$ & 130 \\
\hline The intravascular cooling in the treatment of stroke $2 / 3$ trial & Phase II/III, randomized, case-control & $\mathrm{TH}+\mathrm{t}-\mathrm{PA}$ & 400 \\
\hline Mild hypothermia in acute ischemic stroke & Phase II, randomized, case-control & Mild TH & 36 \\
\hline Caffeinol hypothermia protocol & Phase I/II, non-randomized, case-control & $\mathrm{TH}+$ caffeinol & 30 \\
\hline Hypothermia in children after trauma & Phase II, randomized, case-control & Moderate TH & 340 \\
\hline Hypothermia in traumatic brain injury in children (HiTBIC) & Phase II/III, randomized, case-control & $\mathrm{TH}$ & 50 \\
\hline The prophylactic hypothermia trial to lessen traumatic brain injury & Phase III, randomized, case-control & $\mathrm{TH}$ & 512 \\
\hline Discrete hypothermia in the management of traumatic brain injury & Phase III, randomized, case-control & $\mathrm{TH}$ & 25 \\
\hline $\begin{array}{l}\text { Mild hypothermia and supplemental magnesium sulfate infusion in } \\
\text { severe traumatic brain injury (TBI) subjects }\end{array}$ & Phase II, randomized, case-control & $\begin{array}{l}\mathrm{TH}+\text { magnesium } \\
\text { sulfate }\end{array}$ & 105 \\
\hline Hypothermia in children after trauma & Phase III, randomized, case-control & $\mathrm{TH}$ & 340 \\
\hline Therapeutic hypothermia for severe traumatic brain injury in Japan & Phase III, randomized, case-control & Mild TH & 300 \\
\hline
\end{tabular}

*Data adapted from www.clinicaltrials.gov 
promising and the complication rate was similar to normothermic group (Levi et al., 2010). Nevertheless, larger prospective trials for $\mathrm{TH}$ in SCI are needed before its routine use can be recommended.

In conclusion, it seems that by determining optimal $\mathrm{TH}$ parameters and appropriate clinical applications, cooling therapy has a strong potential to become a valuable neuroprotective intervention in many neurological events. In addition, it is very likely that combining neuroprotective strategies, both invasive and noninvasive, will yield better outcomes than a single approach could. Therefore, the rapid induction of hypothermia to alter deep brain

\section{REFERENCES}

Abate, M., Cadore, B., and Citerio, G. (2008). Hypothermia in adult neurocritical patients: a very hot strategy not to be hibernated yet! Minerva Anestesiol. 74, 425-430.

Abou-Chebl, A., DeGeorgia, M. A., Andrefsky, J. C., and Krieger, D. W. (2004). Technical refinements and drawbacks of a surface cooling technique for the treatment of severe acute ischemic stroke. Neurocrit. Care 1, 131-143.

Adelson, P. D., Ragheb, J., Muizelaar, J. P., Kanev, P., Brockmeyer, D., Beers, S. R., Brown, S. D., Cassidy, L. D., Chang, Y., and Levin, H. (2005). Phase II clinical trial of moderate hypothermia after severe traumatic brain injury in children. $\mathrm{Neu}$ rosurgery $56,740$.

Aiyagari, V., and Diringer, M. N. (2007). Fever control and its impact on outcomes: what is the evidence? J. Neurol. Sci. 261, 39-46.

Akaji, K., Suga, S., Fujino, T., Mayanagi, K., Inamasu, J., Horiguchi, T., Sato, S., and Kawase, T. (2003). Effect of intra-ischemic hypothermia on the expression of c-Fos and c-Jun, and DNA binding activity of AP-1 after focal cerebral ischemia in rat brain. Brain Res. 975, 149-157.

Alty, J. E., and Ford, H. L. (2008). Multisystem complications of hypothermia: a case of recurrent episodic hypothermia with a review of the pathophysiology of hypothermia. Postgrad. Med. J. 84, 282-286.

Anei, R., Sakai, H., Iihara, K., and Nagata, I. (2010). Effectiveness of brain hypothermia treatment in patients with severe subarachnoid hemorrhage: comparisons at a single facility. Neurol. Med. Chir. (Tokyo) 50, 879-883.

Arcure, J., and Harrison, E. (2009). A review of the use of early hypothermia in the treatment of traumatic brain injuries. J. Spec. Oper. Med. 9, 22.

Bandschapp, O., and Iaizzo, P. A. (2011). Induction of therapeutic hypothermia requires modulation of thermoregulatory defenses. Ther. Hypothermia Temp. Manag. X, 1-9.
Basso, D. M., Beattie, M. S., and Bresnahan, J. C. (1996). Graded histological and locomotor outcomes after spinal cord contusion using the NYU weight-drop device versus transection. Exp. Neurol. 139, 244-256.

Bernard, S. A., and Buist, M. (2003). Induced hypothermia in critical care medicine: a review. Crit. Care Med. 31, 2041.

Bratton, S., Chestnut, R., Ghajar, J., McConnell Hammond, F., Harris, O., Hartl, R., Manley, G., Nemecek, A., Newell, D., and Rosenthal, G. (2007). Brain Trauma Foundation, American Association of Neurological Surgeons; Congress of Neurological Surgeons; Joint Section on Neurotrauma and Critical Care; AANS/CNS. Guidelines for the management of severe traumatic brain injury. II. Hyperosmolar therapy. J. Neurotrauma 24(Suppl. 1), S14-S20.

Brooke, O. G., Harris, M., and Salvosa, C. B. (1973). The response of malnourished babies to cold. J. Physiol. (Lond.) 233, 75-91.

Buchan, A., and Pulsinelli, W. A. (1990). Hypothermia but not the N-methylD-aspartate antagonist, MK-801, attenuates neuronal damage in gerbils subjected to transient global ischemia. J. Neurosci. 10, 311.

Busto, R., Dietrich, W. D., Globus, M. Y., and Ginsberg, M. D. (1989a). The importance of brain temperature in cerebral ischemic injury. Stroke 20, 1113-1114.

Busto, R., Globus, M., Dietrich, W. D., Martinez, E., Valdes, I., and Ginsberg, M. D. (1989b). Effect of mild hypothermia on ischemia-induced release of neurotransmitters and free fatty acids in rat brain. Stroke 20, 904.

Cappuccino, A., Bisson, L. J., Carpenter, B., Marzo, J., Dietrich, W. D. III, and Cappuccino, H. (2010). The use of systemic hypothermia for the treatment of an acute cervical spinal cord injury in a professional football player. Spine 35, E57-E62.

Castren, M., Nordberg, P., Svensson, L., Taccone, F., Vincent, J. L., Desruelles, D., Eichwede, F., Mols, P., Schwab, T., Vergnion, M., Storm,

temperatures seems to be a promising candidate to be a component of multimodal clinical strategies.

\section{ACKNOWLEDGMENTS}

The authors express their gratitude to Eliza W. Hartley for her meticulous work in preparing the manuscript. Funding Source: This study was supported, in part, by the Institute for Engineering and Medicine Seed Grant Program, University of Minnesota, Minneapolis, MN, USA, and by a generous donation from the family of Stanley S. Hubbard.

C., Pesenti, A., Pachl, J., Guérisse, F., Elste, T., Roessler, M., Fritz, H., Durnez, P., Busch, H. J., Inderbitzen, B., and Barbut, D. (2010). Intraarrest transnasal evaporative cooling: a randomized, prehospital, multicenter study (PRINCE: Pre-ROSC IntraNasal Cooling Effectiveness). Circulation 122, 729-736.

Chen, J., Ji, X., Ding, Y., Luo, Y., Cheng, H., and Ling, F. (2009). A novel approach to reduce hemorrhagic transformation after interventional management of acute stroke: catheter-based selective hypothermia. Med. Hypotheses 72, 62-63.

Clifton, G. L., Allen, S., Barrodale, P., Plenger, P., Berry, J., Koch, S., Fletcher, J., Hayes, R. L., and Choi, S. C. (1993). A phase II study of moderate hypothermia in severe brain injury. J. Neurotrauma 10, 263-271.

Clifton, G. L., Jiang, J. Y., Lyeth, B. G., Jenkins, L. W., Hamm, R. J., and Hayes, R. L. (1991). Marked protection by moderate hypothermia after experimental traumatic brain injury. J. Cereb. Blood Flow Metab. 11, 114-121.

Clifton, G. L., Miller, E. R., Choi, S. C., Levin, H. S., McCauley, S., Smith, K. R. Jr., Muizelaar, J. P., Wagner, F. C. Jr., Marion, D. W., and Luerssen, T. G. (2001). Lack of effect of induction of hypothermia after acute brain injury. N. Engl. J. Med. 344, 556-563.

Clifton, G. L., Valadka, A., Zygun, D., Coffey, C. S., Drever, P., Fourwinds, S., Janis, L. S., Wilde, E., Taylor, P., and Harshman, K. (2011). Very early hypothermia induction in patients with severe brain injury (the National Acute Brain Injury Study: Hypothermia II): a randomised trial. Lancet Neurol. 10, 131-139.

De Georgia, M., Krieger, D., AbouChebl, A., Devlin, T., Jauss, M., Davis, S., Koroshetz, W., Rordorf, G., and Warach, S. (2004). Cooling for acute ischemic brain damage (COOL AID). Neurology 63, 312.

Den Hertog, H. M., van der Worp, $H$. B., Tseng, M. C., and Dippel, D. W. (2009). Cooling therapy for acute stroke. Cochrane Database Syst. Rev. 21, CD001247.

Dietrich, W. D., Alonso, O., Busto, R., Globus, M. Y. T., and Ginsberg, M. D. (1994). Post-traumatic brain hypothermia reduces histopathological damage following concussive brain injury in the rat. Acta $\mathrm{Neu}$ ropathol. 87, 250-258.

Dietrich, W. D. III. (2009). Therapeutic hypothermia for spinal cord injury. Crit. Care Med. 37(Suppl.), S238S242.

Dippel, D., Van Breda, E., Van Gemert, H., Van der Worp, H., Meijer R., Kappelle, L., and Koudstaal, P. (2001). Effect of paracetamol (acetaminophen) on body temperature in acute ischemic stroke: a doubleblind, randomized phase II clinical trial. Stroke 32, 1607.

Dippel, D. W., van Breda, E. J., van der Worp, H. B., van Gemert, H. M., Meijer, R. J., Kappelle, L. J., and Koudstaal, P. J. (2003). Effect of paracetamol (acetaminophen) and ibuprofen on body temperature in acute ischemic stroke PISA, a phase II double-blind, randomized, placebocontrolled trial [ISRCTN98608690]. BMC Cardiovasc. Disord. 3, 2. doi:10.1186/1471-2261-3-2

Drake, C., and Jory, T. (1962). Hypothermia in the treatment of critical head injury. Can. Med. Assoc. J. 87, 887 .

Duz, B., Oztas, E., Erginay, T., Erdogan, E., and Gonul, E. (2007). The effect of moderate hypothermia in acute ischemic stroke on pericyte migration: an ultrastructural study. Cryobiology 55, 279-284.

Els, T., Oehm, E., Voigt, S., Klisch, J., Hetzel, A., and Kassubek, J. (2006). Safety and therapeutical benefit of hemicraniectomy combined with mild hypothermia in comparison with hemicraniectomy alone in patients with malignant ischemic stroke. Cerebrovasc. Dis. 21, 79-85.

Fay, T. (1943). Observations on generalized refrigeration in cases of severe cerebral trauma. Assoc. Res. Nerv. Ment. Dis. Proc. 24, 611-619. 
Froehler, M. T., and Ovbiagele, B. (2010). Therapeutic hypothermia for acute ischemic stroke. Expert Rev. Cardiovasc. Ther. 8, 593-603.

Georgiadis, D., Schwarz, S., Kollmar, R., and Schwab, S. (2001). Endovascular cooling for moderate hypothermia in patients with acute stroke: first results of a novel approach. Stroke 32, 2550.

Gott, V. L. (2005). Lillehei, Lewis, and Wangensteen: the right mix for giant achievements in cardiac surgery. Ann. Thorac. Surg. 79, S2210-S2213.

Guluma, K. Z., Hemmen, T. M., Olsen, S. E., Rapp, K. S., and Lyden, P. D. (2006). A trial of therapeutic hypothermia via endovascular approach in awake patients with acute ischemic stroke: methodology. Acad. Emerg. Med. 13, 820-827.

Guluma, K. Z., Oh, H., Yu, S. W., Meyer, B. C., Rapp, K., and Lyden, P. D. (2008). Effect of endovascular hypothermia on acute ischemic edema: morphometric analysis of the ICTuS trial. Neurocrit. Care 8, 42-47.

Gunn, A., and Thoresen, M. (2006). Hypothermic neuroprotection. NeuroRx 3, 154-169.

Harms, H., Prass, K., Meisel, C., Klehmet, J., Rogge, W., Drenckhahn, C., Göhler, J., Bereswill, S., Göbel, U., Wernecke, K. D., Wolf, T., Arnold, G., Halle, E., Volk, H. D., Dirnagl, U., and Meisel, A. (2008). Preventive antibacterial therapy in acute ischemic stroke: a randomized controlled trial. PLoS One 14, 3(5):e2158.

Hashimoto, T., Yonetani, M., and Nakamura, H. (2004). Selective brain hypothermia protects against hypoxic-ischemic injury in newborn rats by reducing hydroxyl radical production. Kobe J. Med. Sci. 49, 83-92.

Hemmen, T. M., Raman, R., Guluma, K. Z., Meyer, B. C., Gomes, J. A., CruzFlores, S., Wijman, C. A., Rapp, K. S., Grotta, J. C., Lyden, P. D., and ICTuSL Investigators. (2010). Intravenous thrombolysis plus hypothermia for acute treatment of ischemic stroke (ICTuS-L). Final results. Stroke 41, 2265-2270.

Hendrick, E. (1959). The use of hypothermia in severe head injuries in childhood. Arch. Surg. 79, 362.

Henker, R. A., Brown, S. D., and Marion, D. W. (1998). Comparison of brain temperature with bladder and rectal temperatures in adults with severe head injury. Neurosurgery 42 , 1071.

Iampietro, P. F., Vaughan, J. A., Goldman, R. F., Kreider, M. B., Masucci, F., and Bass, D. E. (1960). Heat production from shivering. J. Appl. Physiol. 15, 632-634.

Jessen, K. (1980). An assessment of human regulatory nonshivering thermogenesis. Acta Anaesthesiol. Scand. 24, 138-143.

Jiang, J. Y., Lyeth, B. G., Kapasi, M., Jenkins, L., and Povlishock, J. (1992). Moderate hypothermia reduces blood-brain barrier disruption following traumatic brain injury in the rat. Acta Neuropathol. $84,495-500$.

Jordan, J. D., and Carhuapoma, J. R. (2007). Hypothermia: comparing technology. J. Neurol. Sci. 261, 35-38.

Kallmünzer, B., Krause, C., Pauli, E., Beck, A., Breuer, L., Köhrmann, M., and Kollmar, R. (2011). Standardized antipyretic treatment in stroke: a pilot study. Cerebrovasc. Dis. 31, 382-389.

Kammersgaard, L., Rasmussen, B., Jorgensen, H., Reith, J., Weber, U., and Olsen, T. (2000). Feasibility and safety of inducing modest hypothermia in awake patients with acute stroke through surface cooling: a case-control study: the Copenhagen Stroke Study. Stroke 31, 2251.

Karibe, H., Chen, J., Zarow, G. J., Graham, S. H., and Weinstein, P. R. (1994). Delayed induction of mild hypothermia to reduce infarct volume after temporary middle cerebral artery occlusion in rats. J. Neurosurg. 80, 112-119.

Kasner, S. E., Wein, T., Piriyawat, P., Villar-Cordova, C. E., Chalela, J. A., Krieger, D. W., Morgenstern, L. B., Kimmel, S. E., Grotta, J. C., and Koennecke, H. C. (2002). Acetaminophen for altering body temperature in acute stroke: a randomized clinical trial ${ }^{\star}$ editorial comment: a randomized clinical trial. Stroke 33, 130.

Keller, E., Imhof, H. G., Gasser, S., Terzic, A., and Yonekawa, Y. (2003). Endovascular cooling with heat exchange catheters: a new method to induce and maintain hypothermia. Intensive Care Med. 29, 939-943.

Keller, E., Mudra, R., Gugl, C., Seule, M., Mink, S., and Frohlich, J. (2009). Theoretical evaluations of therapeutic systemic and local cerebral hypothermia. J. Neurosci. Methods $178,345-349$.

Kim, F., Olsufka, M., Longstreth, W. T. Jr., Maynard, C., Carlbom, D., Deem, S., Kudenchuk, P., Copass, M. K., and Cobb, L. A. (2007). Pilot randomized clinical trial of prehospital induction of mild hypothermia in out-of-hospital cardiac arrest patients with a rapid infusion of 4 degrees $\mathrm{C}$ normal saline. Circulation 115, 3064-3070.
Kim, F., Olsufka, M., Nichol, G., Copass, M. K., and Cobb, L. A (2009). The use of pre-hospital mild hypothermia after resuscitation from out-of-hospital cardiac arrest. J. Neurotrauma 26, 359-363.

Koennecke, H. C., and Leistner, S. (2001). Prophylactic antipyretic treatment with acetaminophen in acute ischemic stroke. Neurology 57, 2301.

Kollmar, R., Blank, T., Han, J. L., Georgiadis, D., and Schwab, S. (2007). Different degrees of hypothermia after experimental stroke: short-and long-term outcome. Stroke 38, 1585.

Kollmar, R., Schellinger, P. D., Steigleder, T., Kohrmann, M., and Schwab, S. (2009). Ice-cold saline for the induction of mild hypothermia in patients with acute ischemic stroke: a pilot study. Stroke 40, 1907-1909.

Konstas, A. A., Neimark, M. A., Laine, A. F., and Pile-Spellman, J. (2007). A theoretical model of selective cooling using intracarotid cold saline infusion in the human brain. J. Appl. Physiol. 102, 1329.

Krieger, D. W., De Georgia, M. A. Abou-Chebl, A., Andrefsky, J. C. Sila, C. A., Katzan, I. L., Mayberg, M. R., and Furlan, A. J. (2001). Cooling for acute ischemic brain damage (cool aid): an open pilot study of induced hypothermia in acute ischemic stroke. Stroke 32, 1847-1854.

Lampe, J. W., and Becker, L. B. (2011). State of the art in therapeutic hypothermia. Annu. Rev. Med. 62, 79-93.

Lazorthes, G., and Campan, L. (1958). Hypothermia in the treatment of craniocerebral traumatism. J. Neurosurg. $15,162$.

Lazzaro, M. A., and Prabhakaran, S. (2008). Induced hypothermia in acute ischemic stroke. Expert Opin. Investig. Drugs 17, 1161-1174.

Lenhardt, R., Orhan-Sungur, M. Komatsu, R., Govinda, R., Kasuya, Y., Sessler, D. I., and Wadhwa, A. (2009). Suppression of shivering during hypothermia using a novel drug combination in healthy volunteers. Anesthesiology 111, 110.

Levi, A. D., Casella, G., Green, B. A., Dietrich, W. D., Vanni, S., Jagid, J., and Wang, M. Y. (2010). Clinical outcomes using modest intravascular hypothermia after acute cervical spinal cord injury. Neurosurgery 66, 670-677.

Levi, A. D., Green, B. A., Wang, M. Y., Dietrich, W. D., Brindle, T., Vanni, S., Casella, G., Elhammady, G., and Jagid, J. (2009). Clinical application of modest hypothermia after spinal cord injury. J. Neurotrauma 26, 407-415.
Linares, G., and Mayer, S. A. (2009). Hypothermia for the treatment of ischemic and hemorrhagic stroke. Crit. Care Med. 37(Suppl.), S243S249.

Liu, L., and Yenari, M. A. (2007). Therapeutic hypothermia: neuroprotective mechanisms. Front. Biosci. 12, 816-825.

Lyden, P. D., Allgren, R. L., Ng, K., Akins, P., Meyer, B., Al-Sanani, F., Lutsep, H., Dobak, J., Matsubara, B. S., and Zivin, J. (2005). Intravascular cooling in the treatment of stroke (ICTuS). Early clinical experience. J. Stroke Cerebrovasc. Dis. 14, 107-114.

MacLellan, C. L., Clark, D. L., Silasi, G., and Colbourne, F. (2009). Use of prolonged hypothermia to treat ischemic and hemorrhagic stroke. J. Neurotrauma 26, 313-323.

Maier, C. M. (1998). Optimal depth and duration of mild hypothermia in a focal model of transient cerebral ischemia: effects on neurologic outcome, infarct size, apoptosis, and inflammation. Stroke 29, 2171.

Maier, C. M., Sun, G. H., Cheng, D., Yenari, M. A., Chan, P. H., and Steinberg, G. K. (2002). Effects of mild hypothermia on superoxide anion production, superoxide dismutase expression, and activity following transient focal cerebral ischemia. Neurobiol. Dis. 11, 28-42.

Marion, D. W., Obrist, W. D., Carlier, P. M., Penrod, L. E., and Darby, J. M. (1993). The use of moderate therapeutic hypothermia for patients with severe head injuries: a preliminary report. J. Neurosurg. 79, 354-362.

Marion, D. W., Penrod, L. E., Kelsey, S. F., Obrist, W. D., Kochanek, P. M., Palmer, A. M., Wisniewski, S. R., and DeKosky, S. T. (1997). Treatment of traumatic brain injury with moderate hypothermia. N. Eng. J. Med. 336, 540-546.

Martin-Schild, S., Hallevi, H., Shaltoni, H., Barreto, A. D., Gonzales, N. R., Aronowski, J., Savitz, S. I., and Grotta, J. C. (2009). Combined neuroprotective modalities coupled with thrombolysis in acute ischemic stroke: a pilot study of caffeinol and mild hypothermia. J. Stroke Cerebrovasc. Dis. 18 , 86-96.

Mayer, S. A., Kowalski, R. G., Presciutti, M., Ostapkovich, N. D., McGann, E., Fitzsimmons, B. F., Yavagal, D. R., Du, Y. E., Naidech, A. M., Janjua, N. A., Claassen, J., Kreiter, K. T., Parra, A., and Commichau, C. .. (2004). Clinical trial of a novel surface cooling system for fever control in neurocritical care patients. Crit. Care Med. 32, 2508-2515. 
McIntyre, L. A., Fergusson, D. A., Hébert, P. C., Moher, D., and Hutchison, J. S. (2003). Prolonged therapeutic hypothermia after traumatic brain injury in adults. JAMA 289, 2992.

Metz, C., Holzschuh, M., Bein, T., Woertgen, C., Frey, A., Frey, I., Taeger, K., and Brawanski, A. (1996). Moderate hypothermia in patients with severe head injury: cerebral and extracerebral effects. J. Neurosurg. $85,533-541$.

Minamisawa, H., Smith, M. L., and Siesjö, B. K. (1990). The effect of mild hyperthermia and hypothermia on brain damage following 5 , 10 , and 15 minutes of forebrain ischemia. Ann. Neurol. 28, 26-33.

Miyazawa, T., Tamura, A., Fukui, S., and Hossmann, K. A. (2003). Effect of mild hypothermia on focal cerebral ischemia. Review of experimental studies. Neurol. Res. 25, 457-464.

Motamedi, G. K., Gonzalez-Sulser, A., Dzakpasu, R., and Vicini, S. (2011). Cellular mechanisms of desynchronizing effects of hypothermia in an in vitro epilepsy model. Neurotherapeutics. doi: 10.1007/s13311-0110078-5. [Epub ahead of print].

Nakashima, K., and Todd, M. M. (1996). Effects of hypothermia on the rate of excitatory amino acid release after ischemic depolarization. Stroke 27, 913.

Nohl, H., and Jordan, W. (1986). The mitochondrial site of superoxide formation. Biochem. Biophys. Res. Commun. 138, 533-539.

Nolan, J., Morley, P., Hoek, T., and Hickey, R. Advancement Life support Task Force of the International Liaison Committee on Resuscitation. (2003). Therapeutic hypothermia after cardiac arrest. An advisory statement by the Advancement Life support Task Force of the International Liaison committee on Resuscitation. Resuscitation 57, 231-235.

Olsen, T. S., Weber, U. J., and Kammersgaard, L. P. (2003). Therapeutic hypothermia for acute stroke. Lancet Neurol. 2, 410-416.

Polderman, K. H. (2004). Keeping a cool head: how to induce and maintain hypothermia. Crit. Care Med. 32, 2558-2560.

Polderman, K. H., Rijnsburger, E. R., Peerdeman, S. M., and Girbes, A. R. J. (2005). Induction of hypothermia in patients with various types of neurologic injury with use of large volumes of ice-cold intravenous fluid. Crit. Care Med. 33, 2744.

Puccio, A. M., Fischer, M. R., Jankowitz, B. T., Yonas, H., Darby, J. M., and Okonkwo, D. O. (2009). Induced normothermia attenuates intracranial hypertension and reduces fever burden after severe traumatic brain injury. Neurocrit. Care 11, 82-87.

Qiu, W., Shen, H., Zhang, Y., Wang, W., Liu, W., Jiang, Q., Luo, M., and Manou, M. (2006). Noninvasive selective brain cooling by head and neck cooling is protective in severe traumatic brain injury. J. Clin. Neurosci. 13, 995-1000.

Rosomoff, H. L., and Holaday, D. A. (1954). Cerebral blood flow and cerebral oxygen consumption during hypothermia. Am. J. Physiol. 179, 85.

Sahuquillo, J., Pérez-Bárcena, J., Biestro, A., Zavala, E., Merino, M. A., Vilalta, A., Poca, M. A., Garnacho, A., Adalia, R., and Homar, J. (2009). Intravascular cooling for rapid induction of moderate hypothermia in severely head-injured patients: results of a multicenter study (IntraCool). Intensive Care Med. 35, 890-898.

Sakoh, M., and Gjedde, A. (2003). Neuroprotection in hypothermia linked to redistribution of oxygen in brain. Am. J. Physiol. Heart Circ. Physiol. 285, H17.

Schubert, G. A., Poli, S., Mendelowitsch, A., Schilling, L., and Thomé, C. (2008). Hypothermia reduces early hypoperfusion and metabolic alterations during the acute phase of massive subarachnoid hemorrhage: a laser-Doppler-flowmetry and microdialysis study in rats. $J$. Neurotrauma 25, 539-548.

Schwab, S., Georgiadis, D., Berrouschot, J., Schellinger, P. D., Graffagnino, C., and Mayer, S. A. (2001). Feasibility and safety of moderate hypothermia after massive hemispheric infarction. Stroke 32, 2033.

Schwab, S., Schwarz, S., Spranger, M., Keller, E., Bertram, M., and Hacke, W. (1998). Moderate hypothermia in the treatment of patients with severe middle cerebral artery infarction. Stroke 29, 2461.

Sedzimir, C. (1959). Therapeutic hypothermia in cases of head injury. J. Neurosurg. 16, 407.

Sessler, D. I. (2008). Temperature monitoring and perioperative thermoregulation. Anesthesiology 109, 318-338.

Shiozaki, T., Hayakata, T., Taneda, M., Nakajima, Y., Hashiguchi, N., Fujimi, S., Nakamori, Y., Tanaka, H., Shimazu, T., and Sugimoto, H. (2001). A multicenter prospective randomized controlled trial of the efficacy of mild hypothermia for severely head injured patients with low intracranial pressure. J. Neurosurg. 94, 50-54.

Shiozaki, T., Nakajima, Y., Taneda, M., Tasaki, O., Inoue, Y., Ikegawa, H., Matsushima, A., Tanaka, H., Shimazu, T., and Sugimoto, H. (2003).
Efficacy of moderate hypothermia in patients with severe head injury and intracranial hypertension refractory to mild hypothermia. J. Neurosurg. 99, 47-51.

Shiozaki, T., Sugimoto, H., Taneda, M., Yoshida, H., Iwai, A., Yoshioka, T., and Sugimoto, T. (1993). Effect of mild hypothermia on uncontrollable intracranial hypertension after severe head injury. J. Neurosurg. 79 , 363-368.

Simosa, H. F., Petersen, D. J., Agarwal, S. K., Burke, P. A., and Hirsch, E. F. (2007). Increased risk of deep venous thrombosis with endovascular cooling in patients with traumatic head injury. Am. Surg. 7, 461-464.

Sydenham, E., Roberts, I., and Alderson, P. (2009). Hypothermia for traumatic head injury. Cochrane Database Syst. Rev. CD001048.

Tokutomi, T., Miyagi, T., Takeuchi, Y., Karukaya, T., Katsuki, H., and Shigemori, M. (2009). Effect of 35 [degrees] $\mathrm{C}$ hypothermia on intracranial pressure and clinical outcome in patients with severe traumatic brain injury. J. Trauma. 66, 166.

Turrens, J. F., Beconi, M., Barilla, J., Chavez, U. B., and McCord, J. M. (1991). Mitochondrial generation of oxygen radicals during reoxygenation of ischemic tissues. Free Radic. Res. Commun. 12-13(Pt 2), 681-689.

van Breda, E. J., van der Worp, B., van Gemert, M., Meijer, R., Kappelle, J., Koudstaal, P. J., and Dippel, D. W. (2002). PISA. The effect of paracetamol (acetaminophen) and ibuprofen on body temperature in acute stroke: protocol for a phase II double-blind randomised placebocontrolled trial [ISRCTN98608690]. BMC Cardiovasc. Disord. 2, 7. doi:10.1186/1471-2261-2-7

van der Worp, H. B., Macleod, M. R., and Kollmar, R. (2010). Therapeutic hypothermia for acute ischemic stroke: ready to start large randomized trials[quest]. J. Cereb. Blood Flow Metab. 30, 1079-1093.

van der Worp, H. B., Sena, E. S., Donnan, G. A., Howells, D. W., and Macleod, M. R. (2007). Hypothermia in animal models of acute ischaemic stroke: a systematic review and meta-analysis. Brain 130(Pt 12), 3063-3074.

Varon, J., and Acosta, P. (2008). Therapeutic hypothermia: past, present, and future. Chest 133, 1267-1274.

Wang, H., Olivero, W., Lanzino, G., Elkins, W., Rose, J., Honings, D., Rodde, M., Burnham, J., and Wang, D. (2004). Rapid and selective cerebral hypothermia achieved using a cooling helmet. J. Neurosurg. 100, 272-277.

Xue, D., and Huang, Z. (1992). Immediate or delayed mild hypothermia prevents focal cerebral infarction. Brain Res. 587, 66-72.

Yenari, M. A., Wijman, C., and Steinberg, G. (2008). "Effects of hypothermia on cerebral metabolism, blood flow, and autoregulation," in Therapeutic hypothermia, eds S. A. Mayer and D. I. Sessler (New York: Marcel Dekker) 141-178

Yu, C. G., Jimenez, O., Marcillo, A. E., Weider, B., Bangerter, K., Dietrich, W. D., Castro, S., and Yezierski, R. P. (2000). Beneficial effects of modest systemic hypothermia on locomotor function and histopathological damage following contusioninduced spinal cord injury in rats. J. Neurosurg. 93(Suppl.), 85-93.

Zhang, H., Ren, C., Gao, X., Takahashi, T., Sapolsky, R. M., Steinberg, G. K., and Zhao, H. (2008). Hypothermia blocks [beta]-catenin degradation after focal ischemia in rats. Brain Res. 1198, 182-187.

Zhi, D., Zhang, S., and Lin, X. (2003). Study on therapeutic mechanism and clinical effect of mild hypothermia in patients with severe head injury. Surg. Neurol. 59, 381-385.

Zweifler, R. M., Voorhees, M. E., Mahmood, M. A., and Alday, D. D. (2003). Induction and maintenance of mild hypothermia by surface cooling in non-intubated subjects. J. Stroke Cerebrovasc. Dis. 12, 237-243.

Conflict of Interest Statement: The authors declare that the research was conducted in the absence of any commercial or financial relationships that could be construed as a potential conflict of interest.

Received: 13 September 2011; accepted: 22 November 2011; published online: 27 December 2011.

Citation: Faridar A, Bershad EM, Emiru T, Iaizzo PA, Suarez JI and Divani AA (2011) Therapeutic hypothermia in stroke and traumatic brain injury. Front. Neur. 2:80. doi: 10.3389/fneur.2011.00080

This article was submitted to Frontiers in Endovascular and Interventional Neurology, a specialty of Frontiers in Neurology. Copyright (c) 2011 Faridar, Bershad, Emiru, Iaizzo, Suarez and Divani. This is an open-access article distributed under the terms of the Creative Commons Attribution Non Commercial License, which permits non-commercial use, distribution, and reproduction in other forums, provided the original authors and source are credited. 